J. Clin. Chem. Clin. Biochem.

Vol. 19, 1981, pp. 435-439

\title{
Comparison of Chromogens for the Determination of Horseradish Peroxidase as a Marker in Enzyme Immunoassay
}

\author{
By Bärbel Porstmann
}

Department of Clinical Biochemïstry, Charité, Humboldt-University Berlin,

\section{T. Porstmann}

Department of Clinical Immunology, Charité, Humboldt-University Berlin and

Elsa Nugel

Department of Clinical Biochemistry, Charité, Humboldt-University Berlin

(Received August 15, 1980/January 8, 1981)

Summary: $o$-Phenylenediamine, 2,2'-azino-di(3-ethylbenzthiazoline sulphonic acid-6) (ABTS), $o$-dianisidine and 4-aminoantipyrine were compared as chromogens for the determination of horseradish peroxidase. Highest sensitivity in the determination of horseradish peroxidase-IgG conjugates in dissolved form was obtained with $o$-phenylenediamine. When these conjugates were used in a two-site binding enzyme immunoassay for hepatitis B surface antigen (HBsAg), the steepest calibration curve and the lowest detection limit were obtained when ABTS was used to determine the immune complexes bound to the solid phase.

Non-ionic detergents, such as polyoxyethylene-sorbitol ester, retarded horseradish peroxidase inactivation, resulting in a chromogen-dependent activity rise of horseradish peroxidase.

An optimised determination of horseradish peroxidase is reported, in which the sensitivity of the solid phase enzyme immunoassay is doubled by the use of $o$-dianisidine.

\section{Vergleich von zur Aktivitätsbestimmung von Meerrettich-Peroxidase} als Marker im Enzymimmunoassay venwendeter Chromogene

Zusammenfassung: Die Empfindlịchkeit der Aktivitätsbestimmung von Mecrrettich-Peroxidase wurde mit den Chromogenen $o$-Phenylendiamin, 2,2'-Ażino-di (3-ethylbenzthiazolin-sulfonat-6) (ABTS), o-Dianisidin und 4-Aminoantipyrin verğlichen. An IgG gekoppelte Meerrettich-Peroxidase wird in gelöster Form am empfindlichsten mit $o$-Phenylendiamin bestimmt.

Nach Einsatz der Konjugate in einem zwei-Seiten Enzymimmunoassay zur Bestimmung des Hepatitis B-Oberflächenantigens (HBs Ag) und quantitativer Bestimmung der an die feste Phase gebundenen Immunkomplexe werden die steilste Standardkurve und geringste untere Nachweisgrenze mit ABTS erhalten.

Nichtionische Detergenzien wie Polyoxyethylen-sorbitester verzögern die İnaktivierung von Meerrettich-Peroxidase während dêr Reaktion und führen zụ einer chromogenabhängigen Aktivitätssteigerung der Meerettich-Peroxidase. Es wird eine optimierte Bestimmung von Meerrettich-Peroxidase mit $o$-Dianisidin vorgestellt, wodurch die Empfindlichkeit des Festphase-Enzymimmunoassays verdoppelt werden kann.

\section{Introduction}

Various chromogens can be used for the determination of horseradish peroxidase, a commonly employed' marker enzyme in enzyme immunoassay (EIA). There have been only a few reports of comparisons of sensitiv- ity, or optimization of the determination, and mostly with free enzymes (1-4).

We compared the chromogens 0 -phenylenediamine, 2,2'-azino-di(3-ethylbenzthiazoline sulphonic acid-6) (ABTS), $o$-diannisidine and 4-aminoantipyrine, using 
IgG coupled horseradish peroxidase in dissolved form and bound to a solid phase by an antigen-antibody reaction in an EIA. In addition, the determination of horseradish peroxidase-IgG conjugates was compared with and without addition of non-ionic detergents, since it has been reported that detergents increase the activity of free horseradish peroxidase (5).

\section{Materials and Methods}

Horseradish peroxidase, conjugates, enzyme imm unoassay

Horseradish peroxidase of purity number 2.8 (purity number $=$ $\mathrm{A}_{403 \mathrm{~nm}} / \mathrm{A}_{280 \mathrm{~nm}}$ ) was prepared (7) and coupled to sheep IgG-anti rabbit IgG by means of the two-step glutaraldehyde technique (8). The conjugates were used in a two-site binding tube EIA for the quantitative determination of hepatitis B surface antigen ( $\mathrm{HBsAg}$ ) (9), according to the following principle:

Polystyrene tubes were coated with guinea pig anti $\mathrm{HBsAg} \mathrm{Ig}$ which bound HBsAg. Free antigen determinants further react with rabbit-anti $\mathrm{HBsAg} \mathrm{Ig}$, to which the conjugate was linked. The enzyme activity of the solid phase-bound immune complexes was found to be proportional to the antigen concentration.

Determination of horseradish peroxidase activity

$0.5 \mathrm{ng}$ of horseradish peroxidase-IgG conjugate was allowed to react in $0.2 \mathrm{ml}$ of substrate mixture over a period of $120 \mathrm{~min}$ utes at a temperature of $20^{\circ} \mathrm{C}$. The reaction was stopped at intervals of 10 minutes by adding $0.2 \mathrm{ml}$ of stopping solution.

The following chromogens were used:

o-phenylenediamine (Merck, Darmstadt, FRG), o-dianisidine (Serva, Heidelberg, FRG), phenol and 4-aminoantipyrine (Sigma Chemical Co., St. Louis, Mo., USA), 2,2'-azino-di(3-ethylbenzthiazoline sulphonic acid-6) (ABTS; Boehringer Mannheim GmbH, Mannheim, FRG) together with hydrogen peroxide as oxygen donor.

Activities were determined with and without addition of polyoxyethy lene-sorbitol ester (Tween-20, Serva, Heidelberg, FRG), the concentration being $1 \mathrm{ml}(=1.1 \mathrm{~g})$ of detergent per litre of substrate mixture (4).

In the EIA, $100 \mathrm{ng}$ of conjugate in $0.2 \mathrm{ml}$ was allowed to react with solid phase-bound immune complexes. After tube washing, the enzyme reaction was started by adding $0.2 \mathrm{ml}$ substrate mixture and stopped with $0.2 \mathrm{ml}$ stopping solution 60 minutes later. A Spekol 20 (VEB Carl Zeiss, Jena, GDR) was used to measure absorbance at all optimal absorption points of oxidized chromogens.

\section{Use of o-dianisidine (4)}

Hydrogen peroxide $(0.7 \mathrm{mmol} / \mathrm{l})$ and $o$-dianisidine $(0.32 \mathrm{mmol} / \mathrm{l})$ were dissolved in acetate buffer $(0.01 \mathrm{~mol} / \mathrm{l}), \mathrm{pH} 5.0$. Reactions were stopped by adding various concentrations of hydrochloric acid:

$0.1,0.5,1.0,1.5,2.0,2.5,3.0,4.0$ and $5.0 \mathrm{~mol} / 1$ acid respectively. Maximum absorption of the coloured products were ascertained using a Spekord UV-VIS (VEB Carl Zeiss, Jena, GDR).

\section{Use of o-phenylenediamine}

The optimal conditions were: Hydrogen peroxide ( $1.5 \mathrm{mmol} / \mathrm{l})$ and $o$-phenylenediamine $(4 \mathrm{mmol} / \mathrm{l})$ dissolved in acetate buffer $(0.1 \mathrm{~mol} / \mathrm{l}), \mathrm{pH} 5.0$. The reaction was stopped with $0.1 \mathrm{~mol} / 1$ sulfuric acid, and absorbance was measured at $\lambda=492 \mathrm{~nm}$.

\section{Use of $A B T S(1,10)$}

Hydrogen peroxide $(0.7 \mathrm{mmol} / \mathrm{l})$ and $o$-dianisidine $(0.32 \mathrm{mmol} / \mathrm{l})$ dissolved in acetate buffer $(0.1 \mathrm{~mol} / \mathrm{l}), \mathrm{pH} 4.2$. The reaction was stopped with $1 \mathrm{mmol} / \mathrm{l}$ sodium azide, and absorbance was measured at $\lambda=418 \mathrm{~nm}$.

\section{Use of phenol and 4-aminoantipyrine (2)}

Hydrogen peroxide $(0.8 \mathrm{mmol} / \mathrm{l})$, phenol $(25 \mathrm{mmol} / \mathrm{l})$ and 4-aminoantipyrine ( $2 \mathrm{mmol} / \mathrm{l}$ ) were dissolved in phosphate buffer $(0.1 \mathrm{~mol} / \mathrm{l}), \mathrm{pH} 7.2$. Because the reaction cannot be stopped by azide or acid, the developed oxidized chromogen was directly measured at $\lambda=492 \mathrm{~nm}$ at the end of 10 minute intervals.

Determination of the stability of oxidized chromogens

Enzyme activities of the horseradish peroxidase conjugates, in dissolved form, were followed over 120 minutes, using ABTS, $o$-dianisidine and $o$-phenylenediamine. With the exception of 4-aminoantipyrine, reactions were stopped at intervals of $10 \mathrm{~min}$ utes. Products of reaction were measured immediately after stopping the reaction, as well as 6,24 and 48 hours later; during this time the products were stored at $20^{\circ} \mathrm{C}$ in the dark. The stabilities were compared.

\section{Results}

Optimization of the horseradish peroxidase determination, using 0 -dianisidine

The colouration of oxidized $o$-dianisidine resulting from horseradish peroxidase activity depends on the hydrogen ion concentration of the stopping reagent. At a hydrogen ion concentration of $50 \mathrm{mmol} / \mathrm{l}$ (reaction stopped with $0.1 \mathrm{~mol} / 1$ hydrochloric acid), a yellow colour, $\lambda_{\max }=$ $403 \mathrm{~nm}$, is produced. At higher hydrogen iōn concentrations, the colour shifted to red, $\lambda_{\max }=530 \mathrm{~nm}$ (fig. 1). The maximal absorbance of the red colour at $\lambda=530 \mathrm{~nm}$ increases with increasing hydrogen ion concentration, and was found to be 2.2 times higher at a hydrogen ion concentration of $2.5 \mathrm{~mol} / \mathrm{l}$ (reaction stopped with

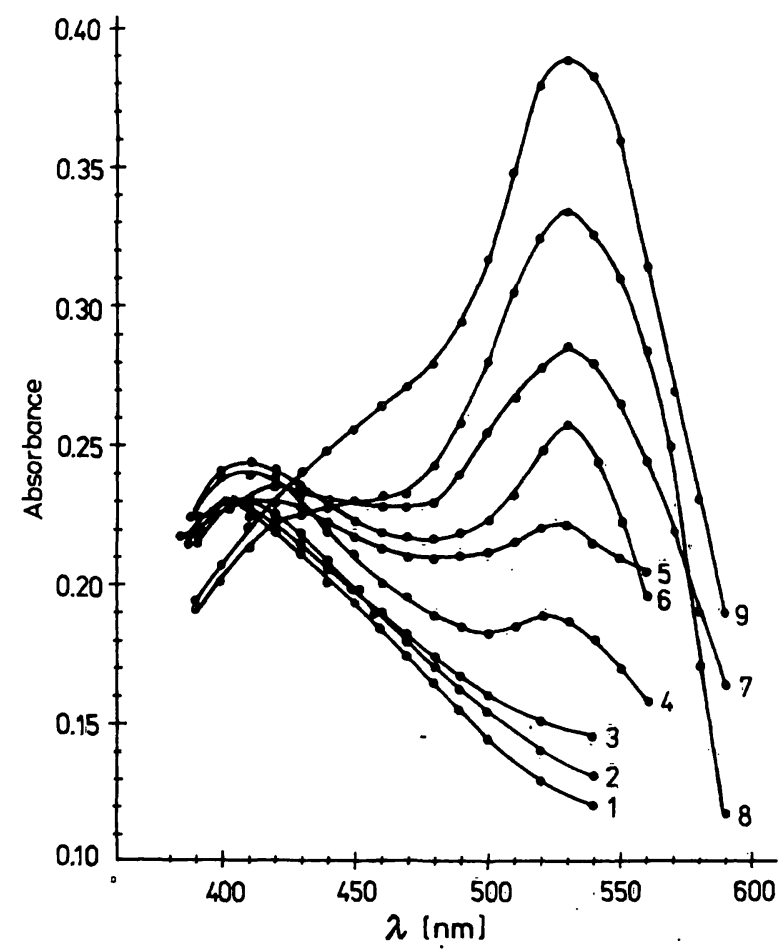

Fig. 1. Absorbance spectrum of oxidized $o$-dianisidine depending on the hydrogen concentration $(\mathrm{mol} / \mathrm{l})$ :

$\begin{array}{llll}1=0.05 \mathrm{~mol} / 1 ; & 2=0.1 \mathrm{~mol} / \mathrm{l}: & 3=0.25 \mathrm{~mol} / \mathrm{l} ; \\ 4=0.5 \mathrm{~mol} / 1 ; & 5=0.75 \mathrm{~mol} / \mathrm{l} ; & 6=1.0 \mathrm{~mol} / 1 ; \\ 7=1.5 \mathrm{~mol} / \mathrm{l} ; & 8=2.0 \mathrm{~mol} / \mathrm{l} ; & 9=2.5 \mathrm{~mol} / 1 .\end{array}$


$5 \mathrm{~mol} / \mathrm{l}$ hydrochloric acid) than that of the yellow colour at $\lambda=403 \mathrm{~nm}$. Addition of Tween-20 to the reaction mixture caused a rise in the activity of coupled horseradish peroxidase, which continued during the reaction. With added detergent, absorbances increased 4.2 times after 60 minutes and 5.3 times after $120 \mathrm{~min}$ utes, compared with absorbances without detergent (fig. 2).

Addition of detergent and measurement of the red colour at $530 \mathrm{~nm}$ gave a higher absorbance than that obtained at $403 \mathrm{~nm}$ for the yellow colour in the absence of detergent. The relative absorbance increase was 5.1fold after $30 \mathrm{~min}, 7.1$-fold after $60 \mathrm{~min}$, and 8.7 -fold after $120 \mathrm{~min}$ of reaction.

\section{Comparison of the horseradish peroxidase} determination, using $o$-dianisidine, $o$-phenylenediamine, ABTS and 4-aminoantipyrine

\section{Conjugated horseradish peroxidase in dissolved form}

By adding detergent to the reaction mixture, the increase of absorbance was only 1.06 -fold after 60 minutes and 1.08 -fold after 120 minutes with $o$-phenylenediamine.

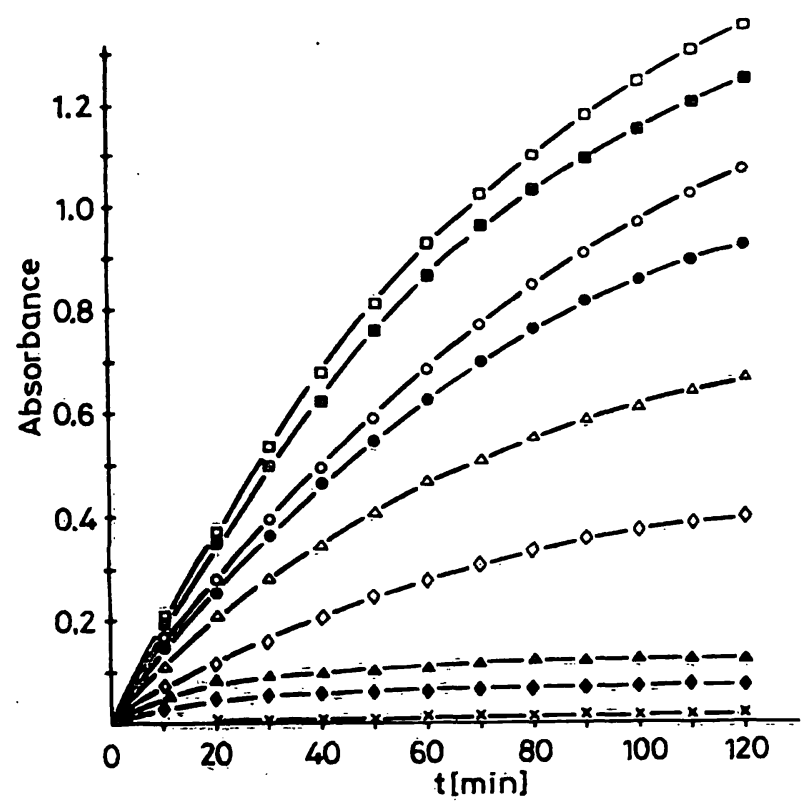

Fig. 2. Horscradish peroxidase kinetics for the same horseradish peroxidase-IgG conjugate concentration, using various chromogens. Absorbance was measured at the respective absorption maxima:

$x-x$ 4-aminoantipyrine, measurement at $\lambda=492 \mathrm{~nm}$

o-dianisidine, yellow colour, measurement at $\lambda=403 \mathrm{~nm}$

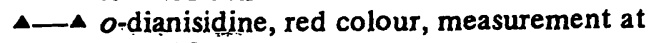
$\lambda=530 \mathrm{~nm}$

$\diamond-\diamond$ o-dianisidine, yellow colour, with detergent measurement at $\lambda \equiv 403 \mathrm{~nm}$

$\Delta-\Delta$ o-dianisidine, red colour, with detergent, measurement at $\lambda=530 \mathrm{~nm}$

$\because$ ABTS, measurement at $\lambda=418 \mathrm{~nm}$

0 - $\mathrm{ABTS}$, with detergent, measurement at $\lambda=418 \mathrm{~nm}$

- O-phenylenediamine, measurement at $\lambda=492 \mathrm{~nm}$

- 0 -phenylenediamine, with detergent, measurement at $\lambda=492 \mathrm{~nm}$.
Increases for $\mathrm{ABTS}$ or 4-aminoantipyrine were 1.10-fold after 60 minutes and 1.16-fold after 120 minutes (fig. 2).

Comparing the highest attainable absorbances for the different chromogens, the highest was obtained with $o$-phenylenediamine, when conjugated horseradish peroxidase in dissolved form was added to the reaction mixture.

With detergent, the absorbance with $o$-phenylenediamine proved to be 1.3 times higher than that obtained with ABTS, twice as high as that with $o$-dianisidine (red colour) and 19 times higher than that with 4-aminoantipyrine.

\section{Solid phase-bound conjugated horseradish peroxidase}

ABTS gave the most sensitive enzyme determination, when horseradish peroxidase-IgG conjugate was determined after binding to the solid phase by the immune reaction (fig. 3). With ABTS the calibration curve was the steepest and the detection was the lowest $(0.25 \mu \mathrm{g} / 1$ HBsAg).

With $o$-phenylenediamine, the calibration curve for higher concentrations of $\mathrm{HBsAg}$ (above $2 \mu \mathrm{g} / \mathrm{l}$ ) was steeper than with $o$-dianisidine (red colour, detergent added), but the detection limits were the same $(1.0 \mu \mathrm{g} / 1 \mathrm{HBsAg})$. When $o$-dianisidine was used without detergent, and the yellow colour was measured, the calibration curve was flattened, and the detection limit went up to $3 \mu \mathrm{g} / \mathrm{HBsAg}$, but with 4-aminoantipyrine it was only $64 \mu \mathrm{g} / \mathrm{l}$.

There was no significant detergent-induced increase in the activity of the solid phase-bound horseradish peroxidase during the antigen-antibody reaction, when ABTS, $o$-phenylenediamine and 4-aminoantipyrine were used. On the other hand application of $o$-dianisidine as chromogen in combination with detergents resulted in 1.7-fold higher absorbance after 60 minutes and 2.0-fold higher absorbance after 120 minutes of reaction.

\section{Stability of coloured products}

Oxidized $o$-dianisidine exhibited the highest stability of all the chromogens tested. Identical absorbance values were obtained from immediate measurement and 6 hours later. Absorbance increased by only 3 per cent after 2 days of sample life, in spite of minor flocculation (fig. 4). The radical cation of ABTS was less stable. Absorbance values after 6 hours were 1.4 per cent below those obtained from immediate measurement, but after 2 days the difference had increased to 5.6 per cent below the initial value. The percentage decrease was the same at all absorbance levels. The lowest stability was recorded for $o$-phenylenediamine; absorbance began to increase a few hours after stopping the reaction, and the percentage increase was found to depend on the concentration of oxidized chromogen. Increases above the initial values (initial values obtained by measurement immediately after stopping the reaction), amounted to 


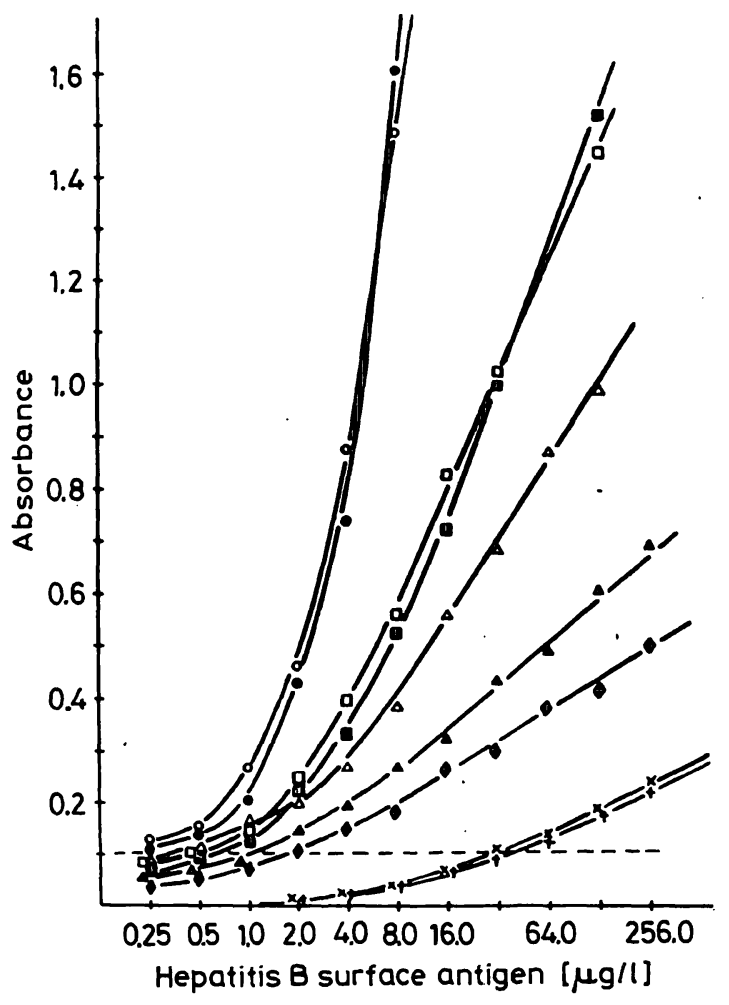

Fig. 3. Calibration curves for quantitative determination of HBsAg in a two-site binding enzyme immunoassay, recorded under identical immunological reaction conditions.

Horseradish peroxidase enzyme reaction at $\mathrm{T}=20^{\circ} \mathrm{C}$ and $\mathrm{t}=60$ minutes, using various chromogens, all under conditions of reaction established as optimal for the given cases

$x-x$ 4-aminoantipyrine, measurement at $\lambda=492 \mathrm{~nm}$

+-+ 4-aminoantipyrine, with detergent, measurement at $\lambda=492 \mathrm{~nm}$

- - -dianisidine, yellow colour, measurement at $\lambda=403 \mathrm{~nm}$

- $o$-dianisidine, red colour, measurement at $\lambda=530 \mathrm{~nm}$

$\triangle \longrightarrow \Delta$ o-dianisidine, red colour, with detergent, measurement at $\lambda=530 \mathrm{~nm}$

- 0 -phenylenediamine, measurement at $\lambda=492 \mathrm{~nm}$

$\square-0$-phenylenediamine, with detergent, measurement at $\lambda=492 \mathrm{~nm}$

- ABTS, measurement at $\lambda=418 \mathrm{~nm}$

$\circ$ - $\mathrm{ABTS}$, with detergent, measurement at $\lambda=418 \mathrm{~nm}$

--- detection limit of HBsAg in the EIA.

76 per cent in the lower range and 5.8 per cent in the upper range.

When 4-aminoantipyrine was used, the absorbance went up drastically, following the addition of azide or acid to stop the reaction. Hence, only immediate measurement was possible.

\section{Discussion}

Horseradish peroxidase is one of the most frequently used marker, enzymes in EIA, but its reaction kinetics are highly complex and have not been fully elucidated. The mechanism of reaction is based, according to W. Cleland'snomenclature (11), on a Ter Bi Ping Pong

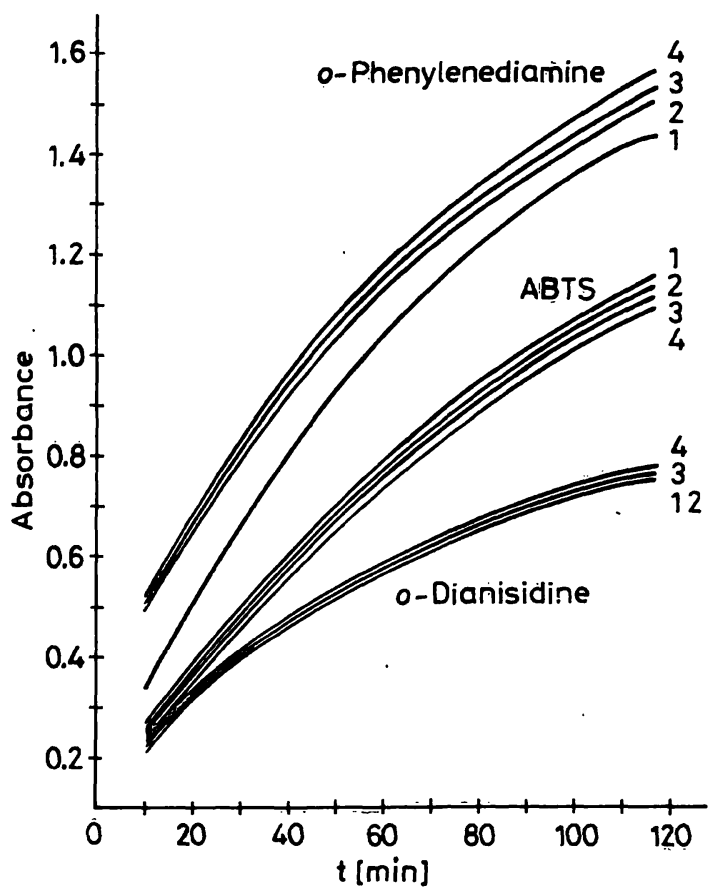

Fig. 4. Stability, after stopping enzyme reaction, of oxidized chromogens: $o$-dianisidine, red colour, measurement at $\lambda=530 \mathrm{~nm} ;$ ABTS, measurement at $\lambda=418 \mathrm{~nm}$; $o$-phenylenediamine, measurement at $\lambda=492 \mathrm{~nm}$. Absorbance measuring

1: immediately after stopping reaction

2: after 6 hours

3: after 24 hours

4: after 48 hours.

principle with partial substrate inhibition caused by excess of hydrogen peroxide during reaction with chromogen; and the extent of enzyme action during reaction depends on the structure and redox potential of the chromogen.

Horseradish peroxidase reaction kinetics with ABTS, $O$-phenylenediamine, and 4-aminoantipyrine were found to differ from those with $o$-dianisidine: Enzyme inactivation was delayed; this might suggest a reduced formation of Compound III, an inactive enzyme-hydrogen peroxide complex, due to a shift of the reaction into the direction of the classical route, described by $R$. Childs (12). In previous investigations we found an activity increase of horseradish peroxidase in the presence of non-ionic detergents such as polyoxyethylene-octylphenol or -sorbitol ester, and it was demonstrated that this effect is not based on the prevention of chromogen deficiency during reaction, but on the delay of inactivation of horseradish peroxidase in the course of substrate reaction $(4,6)$. We assume that detergent might also delay the formation of Compound III, shifting the reaction into the 'classical route, or increase the decomposition of Compound III, rendering enhanced access of chromogen to the inactive compound. This again might explain why, in some chromogens, only a minor rise in activity was obtainable from detergents. The activity, rise of conjugated due to detergent, described in this paper, was 
different from that with free horseradish peroxidase $(4,6)$. The magnitude of the difference depends on the chromogen used.

The most practical and sensitive chromogen for activity measurements of both free and conjugated horseradish peroxidase was found to be $O$-phenylenediamine. However, if conjugated horseradish peroxidase was used in the sandwich EIA and linked to the solid phase via the antigen-antibody reaction, ABTS was the most sensitive chromogen for the determination of activity.

Detergent action was considerably reduced in solid phase-bound horseradish peroxidase. No significant difference between absorbance intensities with and without addition of detergent was detectable, when ABTS, $O$-phenylenediamine or 4-aminoantipyrine were used. However, with $o$-dianisidine, absorbance with detergent was 2 times higher than that without after 120 minutes of reaction. The reduction of detergent action was somewhat surprising, since wall fixation took place by the coupled antibody rather than by the enzyme, and the detergent effect remained fully intact, when immune complex formation took place in a soluble phase (unpublished results). The efficiency of detergent action is more pronounced under the assay conditions, whereas the activity of unbound conjugate is measured in the supernatant after bound/free separation.

Efforts to optimize determination of activity of marker enzymes, which are to be used in EIA must be under- taken under assay conditions. The sensitivity of horseradish peroxidase measurement with 0 -dianisidine as chromogen may be increased if oxidized $o$-dianisidine is transformed into a red colour and detergents are added. For visual evaluation the red colour proved to be much more favourable than the orange colour of oxidized $o$-phenylenediamine.

Our results clearly show that the sensitivity of EIA can be strongly affected by the choice of chromogen for the activity determination of horseradish peroxidase. ABTS, $o$-phenylenediamine and $o$-dianisidine are three chromogens that permit a highly sensitive determination.

The highest stability in the oxidized form, after stopping the reaction, was recorded for $o$-dianisidine; samples could be stored at least one day at room temperature and with the exposure to light before measuring. Similar handling was possible for ABTS, when reaction was stopped by sodium azide. The results with $o$-phenylenediamine, on the other hand, could be easily distorted, due to higher light sensitivity and instability of oxidized chromogen.

The high sensitivity of the determination with ABTS saves material and time. The analytical sensitivity and detection limit obtainable with ABTS were equal to those obtainable with $O$-dianisidine or $O$-phenylenediamine, even when both conjugate concentration and enzyme reaction time were halved.

\section{References}

1. Gallati, H. (1979), J. Clin. Chem. Clin. Biochem. 17, 1-7.

2. Gallati, H. (1977), J. Clin. Chem. Clin. Biochem. 15, $699-703$

3. Saunders, G. C. \& Clinard, E. H. (1977), J. Inf. Dis. 136, 258-267.

4. Porstmann, B., Porstmann, T. \& Gaede, D. (1980), Z. Med. Labor.-Diagn. 21, $201-209$.

5. Porstmann, B. \& Porstmann, T. (1980), Z. Med. Labor.Diagn. 21, 180-181.

6. Porstmann, B., Porstmann, T., Gaede, D., Nugel, E. \& Egger, E. (1981), Clin. Chim. Acta 109, 175-181.

7. Porstmann, B. \& Porstmann, T. (1979), Z. Med. Labor.Diagn. $20,87=95$
8. Avrameas, S. \& Guilbert, B. (1972), Biochimie 54, 837-842.

9. Porstmann, T., Porstmann, B., Schmechta, H., Nugel, E., Meisel, H. \& Geserick, G. (1980), Dt. Gesundh.-Wesen 35, $598-600$.

10. Persijn, J. P. \& Jonker, K. M. (1978), J. Clin. Chem. Clin. Biochem. 16, 531-532.

11. Cleland, W. W. (1963), Biochim. Biophys. Acta 67, 104137.

12. Childs, R. E. \& Bardsley, W. G. (1975), Biochem. J. 145, 93-103.
Dr. med. Bärbel Porstmann Humboldt-University, Charité Dept. of Clinical Biochemistry Schumannstraße 20-21 DDR-1040 Berlin 
